\title{
Combustion of waste oils simulating their injection in blast furnace tuyeres $^{(\cdot)}$
}

\author{
A. Cores*, S. Ferreira*, A. Isidro* and M. Muñiz ${ }^{* *}$
}

\begin{abstract}
A study has been made of the combustion of different waste oils produced in an iron and steel works. Combustion is achieved by injecting the waste oil at flows of $10-20 \mathrm{~kg} / \mathrm{h}$ in a combustion chamber that simulates the conditions of the blast furnace tuyere zone. The waste oil is preheated to $65-90^{\circ} \mathrm{C}$ in order to achieve conditions of fluidity and is injected by spraying into the combustion chamber. During combustion the temperatures and the $\mathrm{CO}_{2}, \mathrm{O}_{2}, \mathrm{CO} \mathrm{N}_{2}$ and $\mathrm{H}_{2}$ contents of the gases in the combustion chamber are constantly recorded. The efficiency of the combustion of each waste oil is determined.
\end{abstract}

\section{Combustión de aceites residuales simulando su inyeccion en las toberas del horno alto}

Resumen

Palabras clave

\begin{abstract}
Se realiza un estudio de la combustión de diferentes aceites residuales que se producen en las plantas siderúrgicas. La combustión se consigue al inyectar el aceite residual, con caudales de $10-20 \mathrm{~kg} / \mathrm{h}$, en una cámara de combustión que simula las condiciones del horno alto en la zona de toberas. El aceite residual se precalienta a $65-90^{\circ} \mathrm{C}$ para conseguir las condiciones de fluidez y se inyecta en la cámara de combustión. Durante la combustión, se registran de modo continuo las temperaturas y los contenidos de $\mathrm{CO}_{2}, \mathrm{O}_{2}, \mathrm{CO}, \mathrm{N}_{2}$ y $\mathrm{H}_{2}$ en los gases de la cámara de combustión. Se calcula la eficiencia de la combustión de cada aceite residual.
\end{abstract}

Horno alto; Aceites residuales; Combustión de aceites residuales; Inyección de aceites residuales.

\section{INTRODUCTION}

Finding suitable ways of disposing of hazardous industrial wastes while preserving human health and the environment is a relatively recent concern in industrialised countries. The dramatic rise in environmental contamination and the worldwide repercussions of some widely publicised events have led to an increase in public awareness of this problem. Since the 1970s governments and public opinion have started to pay attention to the environmental consequences of the inadequate disposal or treatment of this type of waste.

Between 1973 and 2012 six EC environmental programmes issued directives designed to prevent damage to the environment caused by the uncontrolled elimination of waste oils and the guarantee the safe disposal and recycling of wastes. These programmes are showed in Appendix 1.

Iron and steel works, and particularly their rolling mills, produce large amounts of waste oils that must be eliminated by incineration or by other means, as their dumping is prohibited ${ }^{[1]}$.

The company Cockerill Sambre injects in the tuyeres of its Liege BF, at a rate of up to $600 \mathrm{l} / \mathrm{h}$ per tuyere, a waste of which after purification treatment has reduced its water content to $2 \%$ and possesses a calorific capacity of $42,500 \mathrm{~kJ} / \mathrm{kg}$. During the years 1991 and 1992, respectively, 3,900 and 3,700 t of waste oil were injected into the furnace. Given that the waste oil was almost free of water, no problems were detected. Less purified waste oils, with a water content of 35 to $60 \%$, are injected into the tuyeres of BF 4 and BF 5 at Charleroi at a rate of 500

\footnotetext{
(•) Trabajo recibido el día 18 de diciembre de 2007 y aceptado en su forma final el día 15 de octubre de 2008.

* Centro Nacional de Investigaciones Metalúrgicas (CENIM-CSIC). Avda. Gregorio del Amo, 8; 28040 Madrid, Spain.

** ARCELOR Corporación Siderúrgica. Ap. 570, 33280, Gijón, Spain.
} 
t/year per furnace. This impure oil causes problems in the furnace operation and for this reason it is necessary every two days to change the position of the tuyere where the injection takes place, and if the hot metal temperature falls below $1,400^{\circ} \mathrm{C}$ it is necessary to halt the injection of the emulsion ${ }^{[2]}$.

Salzgitter Gruppe has injected into the tuyeres of blast furnces BF A and BF B at Salzgitter Flachstahl a mixture of fuel oil and waste oil at a rate of 75 to $85 \mathrm{~kg} / \mathrm{tHM}$. In the year 2000 the proportion of the injected mixture was $88 \%$ fuel oil and $12 \%$ waste oil, and in 2003 the proportion was 59\% fuel oil and 41\% waste oil ${ }^{[3]}$.

Kobe Steel has injected petroleum coke-oil slurry at $90^{\circ} \mathrm{C}$ into four of the sixteen tuyeres at Kobe BF 1 at a maximum injection rate of $200 \mathrm{~kg} / \mathrm{h}$ of slurry for a time of four months. Using a circumferentially uniform injected slurry distribution system, it was possible to inject a $50 \%$ slurry concentration. The combustibility of the tested slurries was good, but less than the combustibility of heavy oil. The replacement rate of slurry to coke was estimated to be $1.0 \mathrm{~kg} / \mathrm{kg}^{[4]}$.

Voestalpine injects waste oils originates from various sources into one tuyere of $\mathrm{BF} 5$ and $\mathrm{BF} 6$ in Linz. The waste oils have a water content of 2 to $15 \%$ in mass. The injection into the tuyeres impedes the release or disposal of environmentally critical material and ensures the reuse of iron portions in the residues ${ }^{[5]}$.

Carbofer is a patented system that enables mill scale sludge and furnace filter dusts to be recycled by injection into EAFs and blast furnace ${ }^{[6]}$. In Germany, rolling mills annually produce $170,000 \mathrm{t}$ of mill scale contaminated with oil and the automobile industry produces 550,000 t of waste oil. By means of the Carbofer process, the oily mill scale is mixed with fly ash from a thermal power plant and this mixture, after screening, is suitable for pneumatic conveyance to the blast furnace tuyeres, where rates of $38 \mathrm{~kg}$ of oily mill scale/tHM have been injected. Automobile oil has also been injected in the tuyeres at rates of 8 $\mathrm{kg} / \mathrm{tHM}$. In both cases the operation of the furnace has not been affected and it is considered that the injection volumes could be increased ${ }^{[7-9]}$.

In more recent research ${ }^{[10]}$ a thermodynamic study has been made of a) pyrolysis, b) combustion, and c) formation and behaviour of dioxins for the materials carbofer, shredder light fraction, and a group of six plastic materials of different types, in order to analyse the possibility of injecting these materials into the tuyeres of the blast furnace without the formation of ecotoxicants.

The objective of the present work is to utilise and at the same time cleanly dispose of tinnol (a waste oil of animal origin that is extremely difficult to handle, store and destroy) and mixtures of tinnol with other waste oils of mineral origin that are produced in ARCELOR plants through their combustion in blast furnace tuyeres, and also obtaining additional benefits in terms of fuel savings.

In spite of being introduced into Central Europe in XV century, the blast furnace is destined to play an important industrial role in the society of the third millenium. The use of blast furnace to eliminate advanced industrial wastes is now considered normal and is one of the technologies best equipped to achieve a clean atmosphere, free of noxious substances (BAT technologies, The Best Available Technology). Finally, it is important to state that iron and steelmaking in general and the blast furnace in particular are an evolutionary science and technology rather than a series of well-worn, traditional and on occasions apparently obsolete practices.

\section{WASTE OILS}

This work studies the combustion behaviour of the following waste oils:

- New tinnol.

- Depurated mix of 50\% tinnol and 50\% other waste oils.

- Depurated mix of $25 \%$ tinnol and $75 \%$ other waste oils.

- Tinnol depurated by centrifugation.

Tinnol is a viscous oil of animal origin with a density of $0.888 \mathrm{~g} / \mathrm{cm}^{3}$. ARCELOR uses Tinnol as a lubricant for rolled plate in the tandem mill, with an approximate consumption of $2,500 \mathrm{~kg} / \mathrm{day}$. For use, it must previously be emulsified with water at $85^{\circ} \mathrm{C}$, an operation that is carried out by air-stirring in tanks. The tinnol-water mix varies according to the thickness of the plate and oscillates between 6 and $10 \%$ tinnol.

Tinnol incorporates, in origin, chemical additives that facilitate its subsequent separation from water when the emulsion comes into contact with the plate, to prevent oxidation.

After use, the tinnol runs into an overflow channel, situated at a lower level where all the waste materials from rolling, such as oils, mill scale and others, collect, and is subjected to a depuration process ${ }^{[11]}$.

ARCELOR produces annually $1,000 \mathrm{t}$ of waste tinnol and a similar volume of other waste oils of mineral origin used in hydraulic transmission circuits, rolling motor casters and similar uses. These waste oils may be regenerated by contract companies at high cost, a practice that is tolerated due to the impossibility of disposing of these wastes in an easy, rational way without highly costly investments, e.g., 
in incineration installations, special impermeabilised dumps or similar methods.

The purpose of this work is to dispose of the waste oils generated by ARCELOR by injection in blast furnace tuyeres, assuring their complete combustion and a reduction in the specific consumption of coke, and therefore a lower cost of the hot metal.

The interest of the work lies in the fact that requirements for the control of discharges and atmospheric emissions are becoming increasingly rigorous and companies are dedicating their efforts to disposing of contaminating products either by recovering their original characteristics for their subsequent reuse or by converting them into energy sources.

The experimental part of the work has been carried out in a pilot plant for the combustion of pulverised coal, installed at CENIM, complemented by an installation suitable for handling these waste oils.

\subsection{Tinnol recovery plan}

The ARCELOR tinnol recovery plant (Fig. 1) consist of a series of pumping units which pump the dirty tinnol, together with a large quantity of water, from the basement of the rolling mill to the decanter. The mixture is sent to the $90 \mathrm{~m}^{3}$ decanting tank, heated, and separated by gravity into three phases: the upper phase is formed by tinnol, the intermediate phase is water, and sediments are deposited at the bottom of the tank.

When the level of the liquid in the decanter tank is caused to rise, the tinnol, which is floating, spills into a conical drain situated in the upper part of the tank and passes to the $60 \mathrm{~m}^{3}$ waste accumulator tank where the separated tinnols from the decanter tank are stored. Finally, the tinnols are pumped from the accumulator tank to a tanker for disposal.

\subsection{Characteristics of the waste oils}

The chemical composition of the waste oils is indicated in table I. The $\mathrm{C}$ and $\mathrm{H}$ contents of each waste oil have been measured using a CARBO ERBA model EA 1108 chromatographic analysis system. Table I also shows the content of volatilisable elements that are produced by the combustion of the waste oils.

The total sediments correspond to carbonaceous sediments plus inorganic sediments (ashes). From the

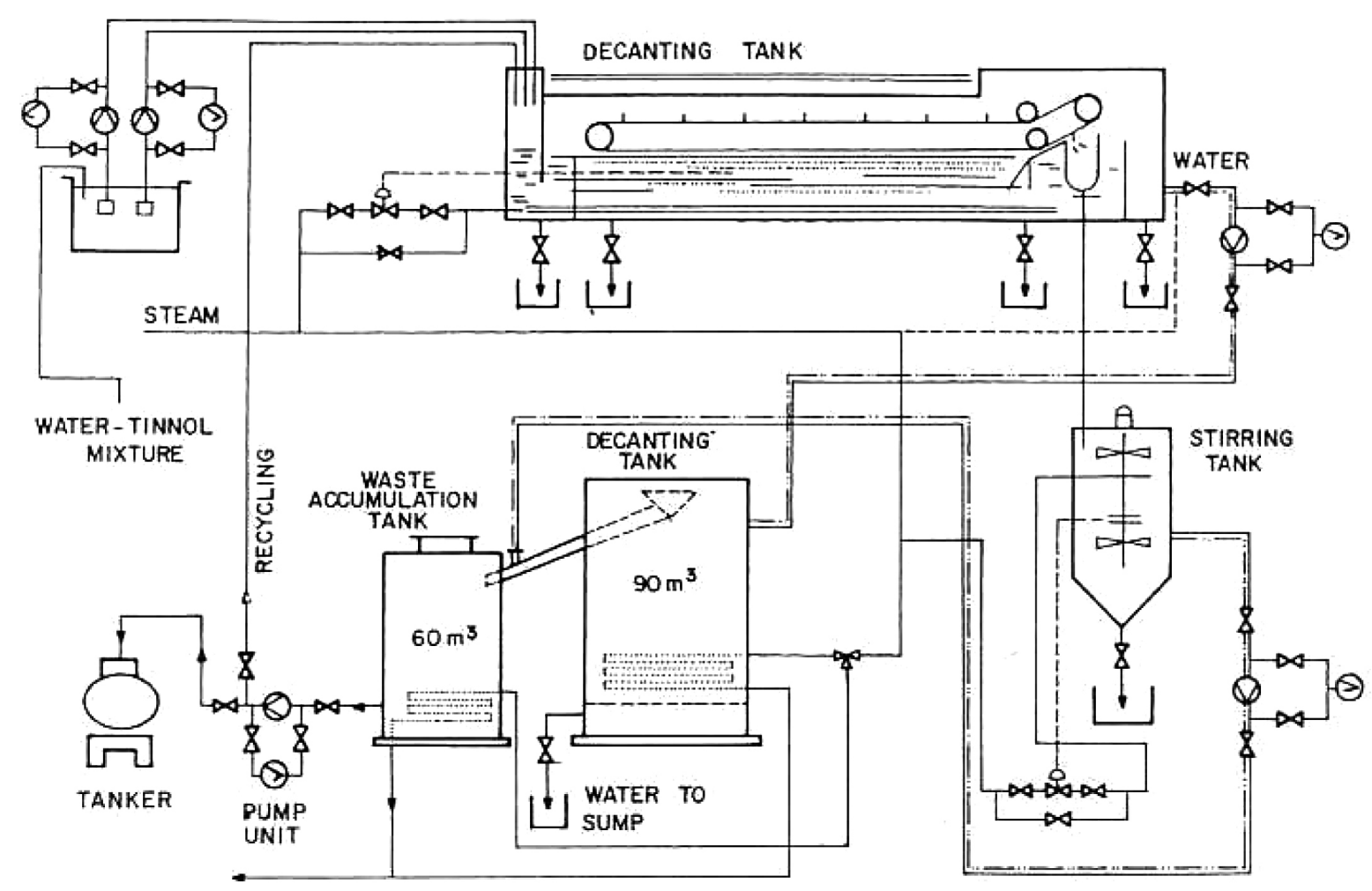

Figure 1. Tinnol recovery plant.

Figura1. Planta de recuperación de tinol. 
COMBUSTION OF WASTE OILS SIMULATING THEIR INJECTION IN BLAST FURNACE TUYERES COMBUSTIÓN DE ACEITES RESIDUALES SIMULANDO SU INYECCION EN LAS TOBERAS DEL HORNO ALTO

Table I. Chemical composition of the waste oils, \% in mass

Tabla I. Composición química de los aceites residuales, \% en masa

\begin{tabular}{|c|c|c|c|c|}
\hline & $\begin{array}{c}\text { New tinnol } \\
50 \% \text { waste oil }\end{array}$ & $\begin{array}{c}50 \% \text { tinnol } \\
75 \% \text { waste oil }\end{array}$ & $25 \%$ tinnol & Depurated tinnol \\
\hline $\mathrm{C}$ & 77.67 & 83.91 & 84.92 & 75.73 \\
\hline $\mathrm{H}$ & 21.93 & 13.90 & 13.30 & 23.91 \\
\hline Humidity & 1.02 & 2.00 & 8.22 & 3.49 \\
\hline Organic matter & 63.25 & 50.18 & 37.98 & 54.21 \\
\hline Total sediments & 35.76 & 47.52 & 53.10 & 39.22 \\
\hline Ash & 33.37 & 39.40 & 42.56 & 35.83 \\
\hline $\mathrm{Cl}^{-}$ & 0.05 & 0.06 & 0.07 & 0.05 \\
\hline S & 0.15 & 0.19 & 0.20 & 0.17 \\
\hline$N$ & 0.87 & 0.71 & 1.04 & 0.94 \\
\hline \multicolumn{5}{|c|}{ Volatile metallic elements produced during combustion, mg/kg } \\
\hline $\mathrm{Cr}$ & 2.0 & 1.1 & 4.5 & 2.3 \\
\hline $\mathrm{Ni}$ & 47.2 & 24.9 & 31.0 & 41.67 \\
\hline $\mathrm{Zn}$ & 24.9 & 28.4 & 29.3 & 27.11 \\
\hline $\mathrm{Cd}$ & 20.0 & 3.2 & 3.1 & 2.3 \\
\hline $\mathrm{Pb}$ & 18.7 & 63.2 & 60.4 & 23.19 \\
\hline $\mathrm{Fe}$ & 355.1 & 362.0 & 376.0 & 359.17 \\
\hline $\mathrm{Mn}$ & 93.0 & 126.0 & 60.2 & 96.43 \\
\hline $\mathrm{Cu}$ & 6.2 & 7.4 & 7.5 & 6.9 \\
\hline
\end{tabular}

values given in Table I, the carbonaceous coal or organic sediments may be calculated to be:

$$
\begin{aligned}
35.76-33.37= & 2.39 \% \text { for new tinnol. } \\
47.52-39.40= & 8.12 \% \text { for } 50 \% \text { tinnol, } 50 \% \\
& \text { waste oil } \\
53.10-42.56= & 10.54 \% \text { for } 25 \% \text { tinnol, } 75 \% \\
& \text { waste oil } \\
39.22-35.83= & 3.39 \% \text { for depurated tinnol. }
\end{aligned}
$$

Table II presents the composition of the waste oil ashes. The sulphated ash content of new tinnol is $<0.2 \%$, which means that its sulphur contribution, in the region of ten thousandths, will not affect the hot metal quality. This data was not determined for the other waste oils.

Thermoanalysis of the waste oils, using a SHIMADZU DT A-50 unit, with the experimental data: atmosphere: air; flow rate: $20 \mathrm{ml} / \mathrm{min}$; and heat rate: $10 \% \mathrm{C} / \mathrm{min}$, makes it possible to determine the parameters displayed in Table III.

Figure 2 shows the thermoanalysis of new tinnol. Melting point, ignition and combustion temperatures are identified. Calorific power is determined.

\section{COMBUSTION OF WASTE OILS IN THE PILOT PLANT}

The combustion of tinnol and of the mix of tinnol with other waste oils was carried out in the pilot plant at CENIM used to perform pulverised coal combustion tests ${ }^{[12}$ and 13$]$. A system has been prepared to inject the waste oil into the tuyere of the pilot plant combustion chamber, which is described in section 3.2.

The combustion of the oil is characterised according to the standard practice established at CENIM for characterising the injection of coal: determination of temperatures, flows, analysis of combustion gases and combustion efficiency.

\subsection{Description of the pilot plant}

The pilot plant has a combustion chamber which simulates as far as possible the conditions in the blast furnace raceway. In the pilot plant, pulverised coal is injected into a tuyere through which a current of hot air is circulating, in order to determine the efficiency of the combustion of different types of coals 
Table II. Chemical composition of waste oils ash, \% in mass

Tabla II. Composición química de la ceniza de los aceites residuales, \% en masa

\begin{tabular}{lcccc}
\hline & $\begin{array}{c}\text { New tinnol } \\
\mathbf{5 0} \% \text { waste oil }\end{array}$ & $\begin{array}{c}50 \text { \% tinnol } \\
\mathbf{7 5} \text { \% waste oil }\end{array}$ & $\mathbf{2 5}$ \% tinnol & Depurated tinnol \\
\hline $\mathrm{SiO}_{2}$ & 1.90 & 1.82 & 2.59 & 1.87 \\
$\mathrm{Al}_{2} \mathrm{O}_{3}$ & 1.17 & 0.78 & 1.12 & 1.21 \\
$\mathrm{Fe}_{2} \mathrm{O}_{3}$ & 93.33 & 92.82 & 91.82 & 94.02 \\
$\mathrm{FeO}$ & 0.45 & 0.58 & 0.47 & 0.49 \\
$\mathrm{CaO}$ & 0.70 & 1.04 & 1.60 & 0.71 \\
$\mathrm{MnO}$ & 0.12 & 0.14 & 0.12 & 0.12 \\
$\mathrm{MgO}$ & 0.01 & 0.01 & 0.02 & 0.01 \\
$\mathrm{TiO}_{2}$ & 0.24 & 0.39 & 0.40 & 0.26 \\
$\mathrm{Na}$ & 0.05 & 0.03 & 0.04 & 0.05 \\
$\mathrm{~K}_{2} \mathrm{O}$ & $<0.01$ & $<0.01$ & $<0.01$ & $<0.01$ \\
$\mathrm{ZnO}$ & 0.035 & 0.034 & 0.034 & 0.036 \\
$\mathrm{CuO}$ & 0.060 & 0.080 & 0.100 & 0.066 \\
$\mathrm{NiO}$ & 0.038 & 0.045 & 0.074 & 0.041 \\
$\mathrm{Cr}_{2} \mathrm{O}_{3}$ & $<0.01$ & $<0.01$ & $<0.01$ & $<0.01$ \\
\hline
\end{tabular}

Table III. Thermoanalysis of the waste oils

Tabla III. Termoanálisis de los aceites residuales

\begin{tabular}{lcccr}
\hline & $\begin{array}{c}\text { New tinnol } \\
\mathbf{5 0} \text { \% waste oil }\end{array}$ & $\begin{array}{c}\mathbf{5 0} \mathbf{7 5} \text { tinnol } \\
\mathbf{7 5} \text { waste oil }\end{array}$ & $\mathbf{2 5 \% \text { tinnol }}$ & $\begin{array}{c}\text { Depurated } \\
\text { tinnol }\end{array}$ \\
\hline Melting point, ${ }^{\circ} \mathrm{C}$ & 48 & 56 & 61 & 53 \\
Ignition temp., $^{\circ} \mathrm{C}$ & 218 & 236 & 241 & 231 \\
${\text { Combustion temp., }{ }^{\circ} \mathrm{C}}^{\text {Calorific power, } \mathrm{kJ} / \mathrm{kg}}$ & 248 & 263 & 277 & 266 \\
\hline
\end{tabular}

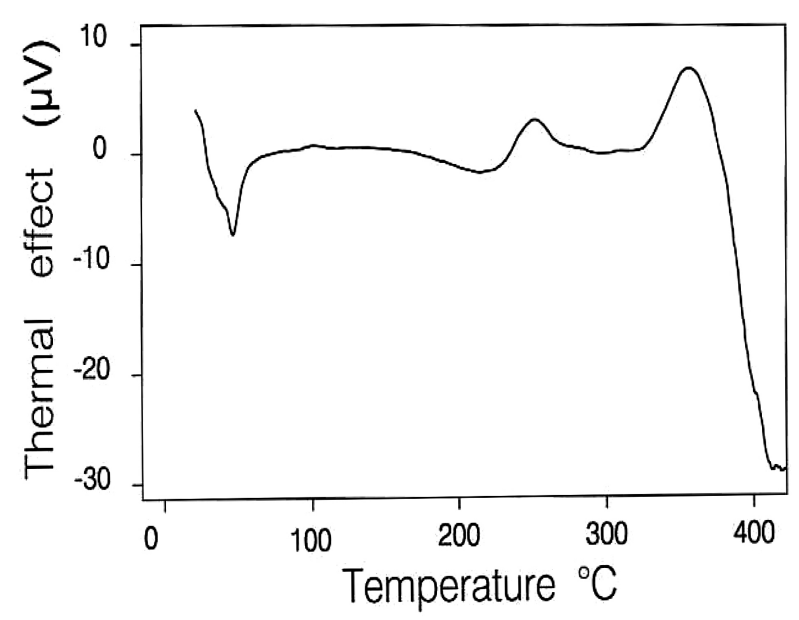

Figure 2. Thermoanalysis of new tinnol.

Figura 2. Termoanálisis del tinol nuevo. to be tested in different conditions of air temperature and coal/air ratios.

Figure 3 shows a diagram of the pilot plant operation. The circulation of the gases is achieved by means of suction. The air is heated with primary air in an atmospheric burner. The combustion and mixing with suctioned air is carried out in a vertical duct of refractory material. After this, oxygen is added until the desired percentage of oxygen is reached.

The temperatures are constantly recorded by four thermocouples. The first measures the temperature of the air before the incorporation of the waste oil, another two are in the combustion chamber and the fourth in the subsequent lined duct.

The gases resulting from the combustion, both of the propane and of the waste oil to be tested, are continuously analysed by means of a sampler situated at the end of the combustion chamber. The sampler 


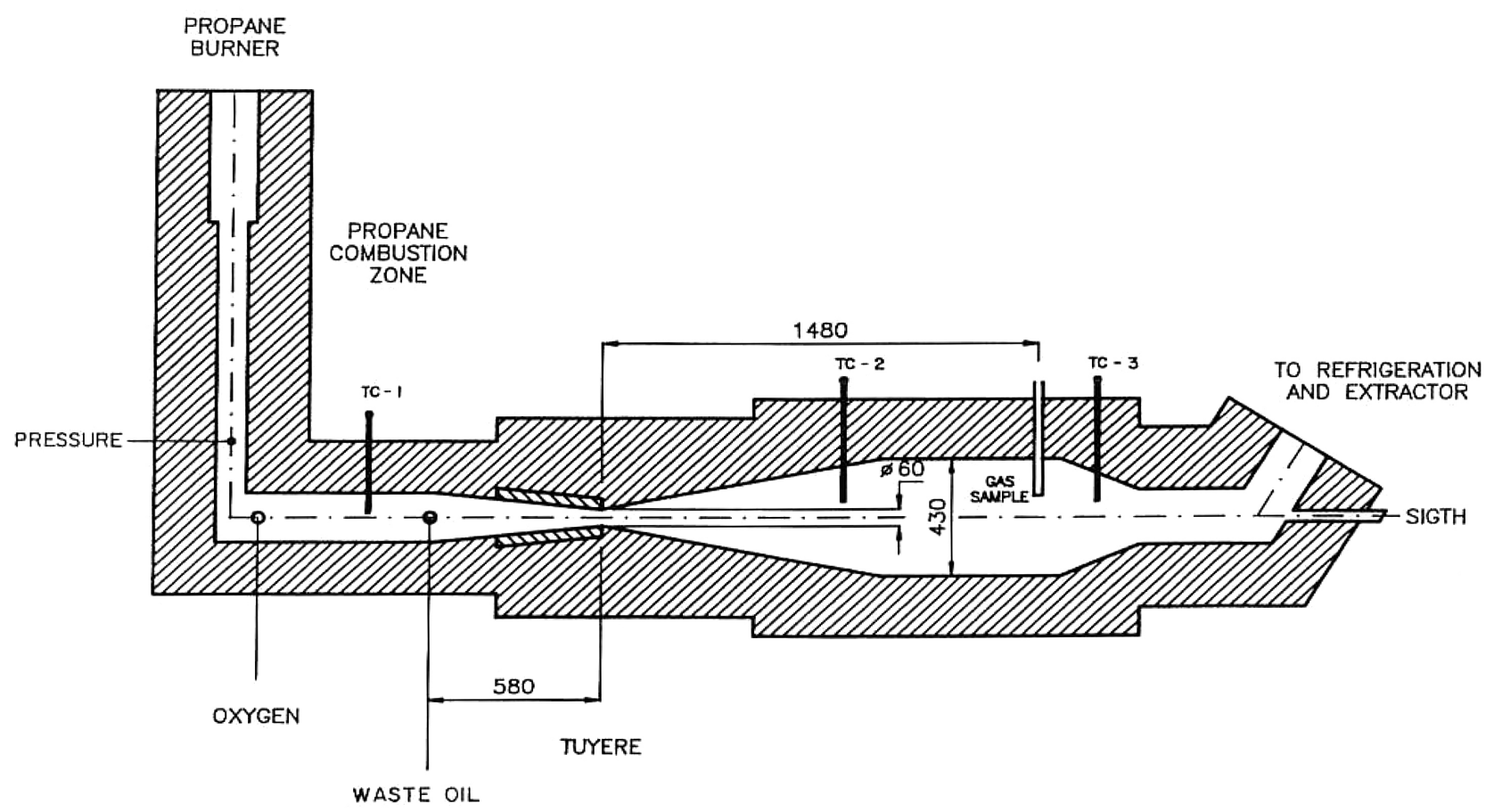

Figure 3. Combustión chamber.

Figura 3. Cámara de combustión.

consists of a pipe of refractory material, after which the gas sample is conveyed to a condenser and a filter, great precaution being taken in order to prevent the entrance of parasite air. A Perkin Elmer model MGA-1200 mass spectrometer is used to determine $\mathrm{CO}_{2}, \mathrm{O}_{2}, \mathrm{CO}, \mathrm{N}_{2}$ and $\mathrm{H}_{2}$. This unit is provided with a continuous recorder and a data collection and processing unit.

The flow of hot air is regulated by opening the parasite air intake valve situated after the combustion chamber. This air flow is measured on the basis of the oxygen flow and its effect on the proportion of oxygen. The maintenance of the flow was verified by the depression flow in the propane combustion section, which is not affected by the introduction of the oxygen or waste oil.

The combustion efficiency of the waste oil carbon content was determined on the basis of the air and fuel flows and of the analyses, as indicated in Appendix 2.

\subsection{Waste oil preheating and injection installation}

The installation, shown in figure 4 consists of a stainless steel preheating recipient of 3501 capacity, at the lower part of which there is an electric heater that may be adjusted to a maximum power of $12 \mathrm{~kW}$.

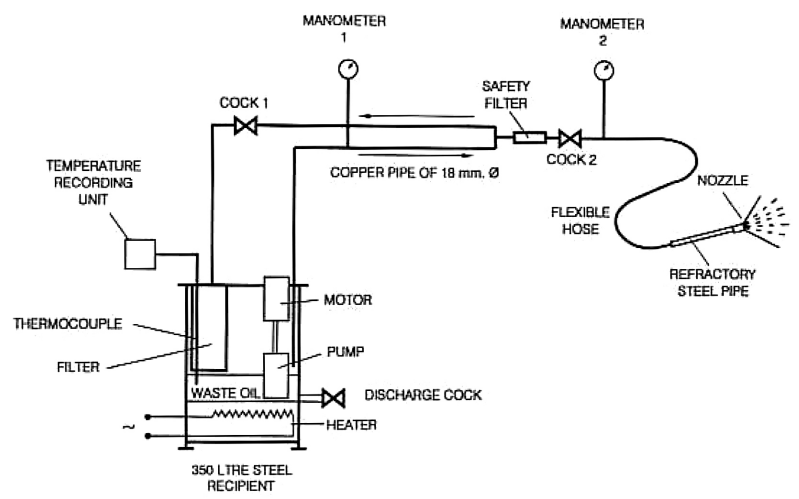

Figure 4. Waste oil preheating and injection.

Figura 4. Precalentamiento e injección del aceite residual.

The recipient is provided with a thermocouple connected to a recorder for the control of the waste oil bath temperature. It is also provided with a filter through which all of the waste oil returning from the installation is made to pass and a centrifugal pump of several steps that transmits pressures of more than $10 \mathrm{~kg} / \mathrm{cm}^{2}$ to the waste oil.

The pressurised waste oil travels through a circuit of copper piping (Fig. 4) with return to the recipient in order to maintain the correct transport 
temperature. At the end of the return the waste oil passes through a filter.

The spraying nozzles used are of a commercial brand especially designed for the spraying of oil. Two types of nozzles have been used to work between 2 and 5 bars, with flows of 0.166 to $0.390 \mathrm{l} / \mathrm{min}$, constructed of AISI 316 stainless steel.

Table IV gives the characteristics of the nozzles used. The calibration data, which is indicated in the table and supplied by the manufacturer, refers to the calibration of the nozzles with water. It is considered that there will be no great variation between water and waste oils. Figure 5 offers a diagram of the nozzles, whose main difference lies in the diameter of the drilled hole B. In figure 6 it is possible to see the position of the spraying nozzle at the moment when it is introduced into the tuyere zone of the combustion chamber.

\subsection{Procedure}

The procedure for all of the tests, except for minor modifications due to the nature of the waste oils used, is as follows:

$50-60 \mathrm{~kg}$ of waste oil is loaded in the preheating recipient and is heated to approximately $65-90^{\circ} \mathrm{C}$. After this, the pump is started up to circulate the waste oil through the return branch in order for its filtering for approximately $20 \mathrm{~min}$.

At the end of this phase cock 2 is opened, with which the oil flows towards the spraying nozzle. With cock 1 it is possible to vary the pressure of the waste oil in the nozzle. The pressure gradually increases until perfect spraying is achieved in the nozzle, as is demonstrated by the presence of a jet of numerous microdrops of waste oil. At that moment the flow in the nozzle is calibrated by introducing it into a tank where it is held for 15 minutes at the selected pressure. The weight of the waste oil that has been sprayed indicates the flow through the nozzle.

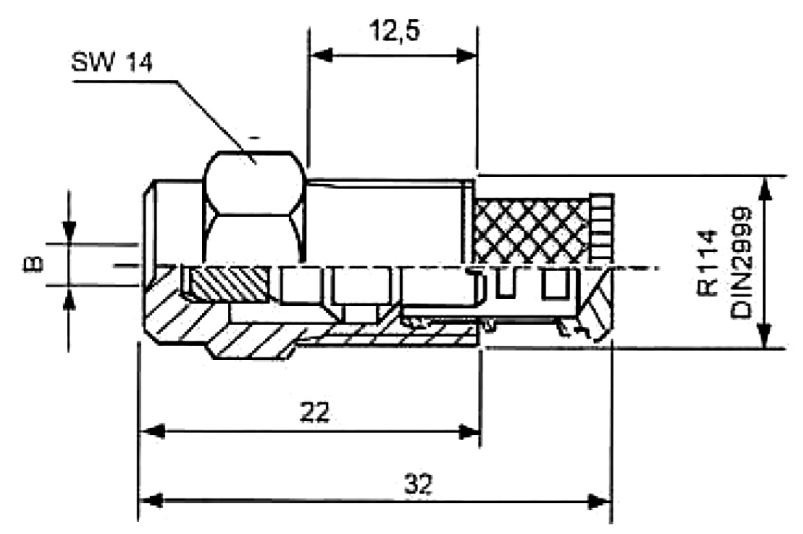

Figure 5. Nozzle.

Figura 5. Boquilla.

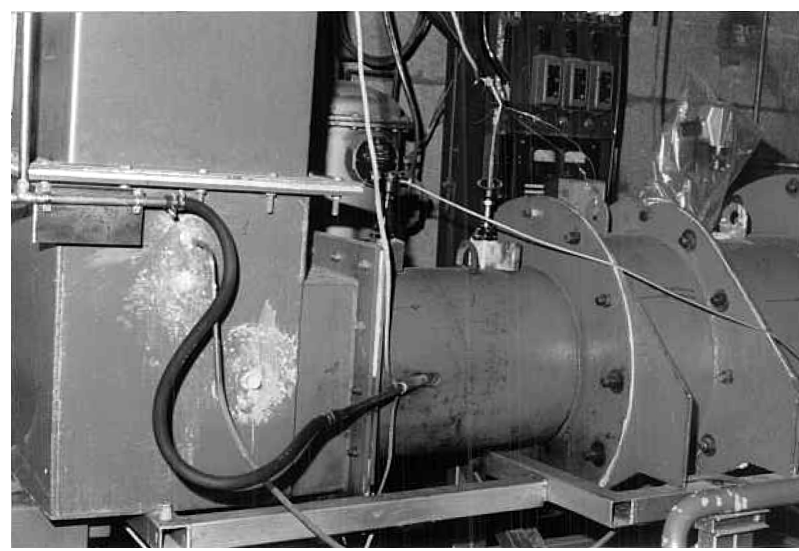

Figure 6. Waste oil injection into the combustion chamber.

Figura 6. Injección del aceite residual en la cámara de combustión.

After its calibration the spraying nozzle is inserted in the tuyere zone and the waste oil is injected for 30 min. After this time the spraying nozzle is removed

Table IV. Nozzle characteristics

Tabla IV. Caracteristica de las boquillas

Nozzle Spraying angle B: Bore diameter $\mathrm{mm}$ 
and recalibrated in the same way as described above. If the two flows coincide, the test has been completed without interruptions in the waste oil supply and is considered to be valid. If the two flows do not coincide, the test is not considered valid.

Other testing conditions are as follows. The combustion chamber is preheated by the combustion of propane, in such a way that when the waste oil is introduced through the tuyere, the combustion chamber is at its operating regime. At this moment, oxygen from a battery of bottles is injected in the combustion chamber, its flow being increased until an oxygen content of $21 \%$ is reached. Once the operation of the combustion chamber with this oxygen flow is established, the waste oil is injected and the addition of oxygen continues for 15 minutes, after which time the supply is cut off. The supply of waste oil continues for a further 15 minutes, after which the spraying nozzle is removed and calibrated as indicated above. At this point the test is considered to be completed. The objective of the first phase, with 21 $\% \mathrm{O}_{2}$, is to simulate more real conditions. The second, without oxygen consumption, makes it possible to verify the regularity of the test during longer times and to a certain extent simulates a higher injection rate.

During each test, determinations are made of the temperature and composition of the gases entering and leaving the combustion chamber, data which, along with the flow and the carbon and hydrogen contents of the waste oil, make it possible to determine the combustion behaviour of each waste oil.

\section{RESULTS}

Tables V to XI present the results of the waste oil combustion tests. During these tests the spraying of the oil in the nozzle was good. A graphic record of temperatures was kept in each test. The tables show a series of testing conditions which correspond to the successive stages of the test, as explained below.

\subsection{Stages}

\subsubsection{Propane combustion gases}

In the combustion chamber the blast is heated to 1,150 $1,300{ }^{\circ} \mathrm{C}$ by the combustion of propane. The temperature is recorded by the thermocouple TC- 1 in figure 4 . The blast speed is $220 \mathrm{~m} / \mathrm{s}$. As a result of combustion, the oxygen content in the blast falls to 9 $12 \%$. Combustion is complete, as is demonstrated by the $0 \% \mathrm{CO}$ content in the combustion gases analysed.

\subsubsection{Gases after adding oxygen}

In the following stage, in order to simulate the real conditions in blast furnace tuyeres it is necessary, in addition to a blast speed of $220 \mathrm{~m} / \mathrm{s}$, for the blast to have a $21 \% \mathrm{O}_{2}$ content. To this end, oxygen from a battery of bottles is added to the propane combustion gases. When the oxygen content exceeds $19 \%$ the conditions are considered valid for the test to commence. As a result of the injection of a large oxygen flow to the combustion chamber, the blast temperature (thermocouple TC-1) drops by between $75-125^{\circ} \mathrm{C}$, as may be observed in the tables.

\subsubsection{Combustion of waste oil with com- burent of approximately $21 \% \mathrm{O}_{2}$}

Once the hot blast with (approx.) $21 \% \mathrm{O}_{2}$ is achieved and the combustion chamber is stabilised, the injection

Table V. Combustion of new tinnol. Preheating temperature: $90^{\circ} \mathrm{C}$. Flow: $20 \mathrm{~kg} / \mathrm{h}$

Tabla V. Combustión de tinol nuevo

\begin{tabular}{|c|c|c|c|c|c|c|c|c|}
\hline & \multirow[t]{2}{*}{$\mathrm{T},{ }^{\circ} \mathrm{C}$} & \multirow[t]{2}{*}{ TC } & \multicolumn{6}{|c|}{ Composition, $\%$} \\
\hline & & & $\mathrm{CO}_{2}$ & $\mathrm{O}_{2}$ & $\mathrm{CO}$ & $\mathrm{N}_{2}$ & $\mathrm{H}_{2}$ & Total \\
\hline Propane combustion gases & 1200 & 1 & 6.9 & 10.6 & 0.0 & 81.0 & 0.0 & 98.5 \\
\hline $\begin{array}{l}\text { Gases after adding } \mathrm{O}_{2} \\
\text { Combustion of waste oil with }\end{array}$ & 1124 & 1 & 6.1 & 19.3 & 0.0 & 73.2 & 0.0 & 98.6 \\
\hline $\begin{array}{l}\text { comburent of approx. } 21 \% \mathrm{O}_{2} \\
\text { Combustion of waste oil with }\end{array}$ & 1306 & 2 & 10.8 & 12.8 & 0.0 & 74.9 & 0.0 & 98.5 \\
\hline $\mathrm{O}_{2}$ impoverished comburent & 1404 & 2 & 12.7 & 3.0 & 0.1 & 82.8 & 0.0 & 98.6 \\
\hline
\end{tabular}


Table VI. Combustion of new tinnol. Preheating temperature: $90{ }^{\circ} \mathrm{C}$. Flow: $17.6 \mathrm{~kg} / \mathrm{h}$

Tabla VI. Combustión de tinol nuevo

\begin{tabular}{lcccccccc}
\hline & $\mathrm{T},{ }^{\circ} \mathrm{C}$ & $\mathrm{TC}$ & \multicolumn{5}{c}{ Composition, \% } \\
\cline { 4 - 9 } & & & $\mathrm{CO}_{2}$ & $\mathrm{O}_{2}$ & $\mathrm{CO}$ & $\mathrm{N}_{2}$ & $\mathrm{H}_{2}$ & Total \\
\hline Propane combustion gases & 1167 & 1 & 6.3 & 11.4 & 0.0 & 81.0 & 0.0 & 98.7 \\
Gases after adding $\mathrm{O}_{2}$ & 1067 & 1 & 5.7 & 20.0 & 0.0 & 73.1 & 0.0 & 98.8 \\
$\begin{array}{l}\text { Combustion of waste oil with } \\
\text { comburent of approx. 21\% } \mathrm{O}_{2}\end{array}$ & 1332 & 2 & 10.1 & 13.6 & 0.0 & 75.2 & 0.0 & 98.9 \\
$\begin{array}{l}\text { Combustion of waste oil with } \\
\mathrm{O}_{2} \text { impoverished comburent }\end{array}$ & 1440 & 2 & 12.7 & 3.3 & 0.0 & 82.7 & 0.0 & 98.7 \\
\hline
\end{tabular}

Table VII. Combustion of mix of $50 \%$ depurated tinnol and $50 \%$ other waste oils Preheating temperature: $65^{\circ} \mathrm{C}$

Flow: $20.1 \mathrm{~kg} / \mathrm{h}$

Tabla VII. Combustión de una mezcla de 50 \% de tinol depurado y $50 \%$ de otros aceites residuales

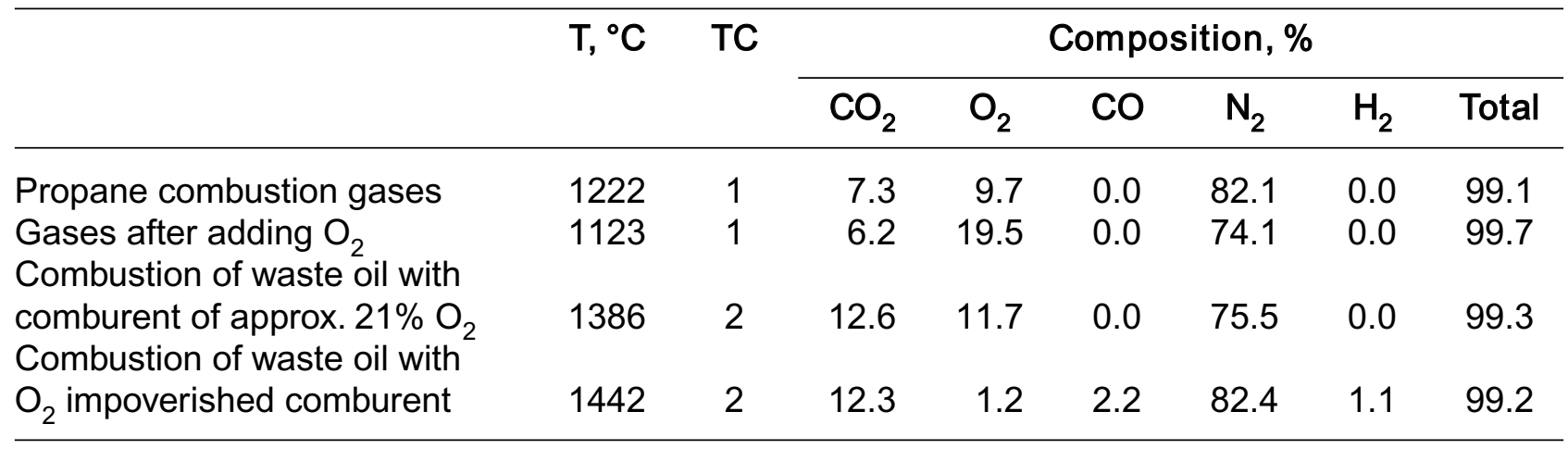

Table VIII. Combustion of mix of $50 \%$ depurated tinnol and $50 \%$ other waste oils Preheating temperature: $65^{\circ} \mathrm{C}$ Flow: $14.6 \mathrm{~kg} / \mathrm{h}$

Tabla VIII. Combustión de una mezcla de 50 \% de tinol depurado y $50 \%$ de otros aceites residuales

\begin{tabular}{lcccccccc}
\hline & T, ${ }^{\circ} \mathrm{C}$ & $\mathrm{TC}$ & \multicolumn{5}{c}{ Composition, \% } \\
\cline { 5 - 9 } & & & $\mathrm{CO}_{2}$ & $\mathrm{O}_{2}$ & $\mathrm{CO}$ & $\mathrm{N}_{2}$ & $\mathrm{H}_{2}$ & Total \\
\hline Propane combustion gases & 1300 & 1 & 6.3 & 11.1 & 0.0 & 81.5 & 0.0 & 98.9 \\
Gases after adding $\mathrm{O}_{2}$ & 1173 & 1 & 5.0 & 19.6 & 0.0 & 75.0 & 0.0 & 99.6 \\
$\begin{array}{l}\text { Combustion of waste oil with } \\
\text { comburent of approx. 21\% } \mathrm{O}_{2}\end{array}$ & 1332 & 2 & 7.4 & 16.5 & 0.0 & 75.3 & 0.0 & 99.2 \\
$\begin{array}{l}\text { Combustion of waste oil with } \\
\mathrm{O}_{2} \text { impoverished comburent }\end{array}$ & 1440 & 2 & 10.2 & 6.0 & 0.0 & 82.7 & 0.0 & 98.9 \\
\hline
\end{tabular}


COMBUSTION OF WASTE OILS SIMULATING THEIR INJECTION IN BLAST FURNACE TUYERES COMBUSTIÓN DE ACEITES RESIDUALES SIMULANDO SU INYECCION EN LAS TOBERAS DEL HORNO ALTO

Table IX. Combustion of mix of $25 \%$ depurated tinnol and $75 \%$ other waste oils

Preheating temperature: $70{ }^{\circ} \mathrm{C}$

Flow: $17.5 \mathrm{~kg} / \mathrm{h}$

Tabla IX. Combustión de una mezcla de $25 \%$ de tinol depurado y $75 \%$ de otros aceites residuales

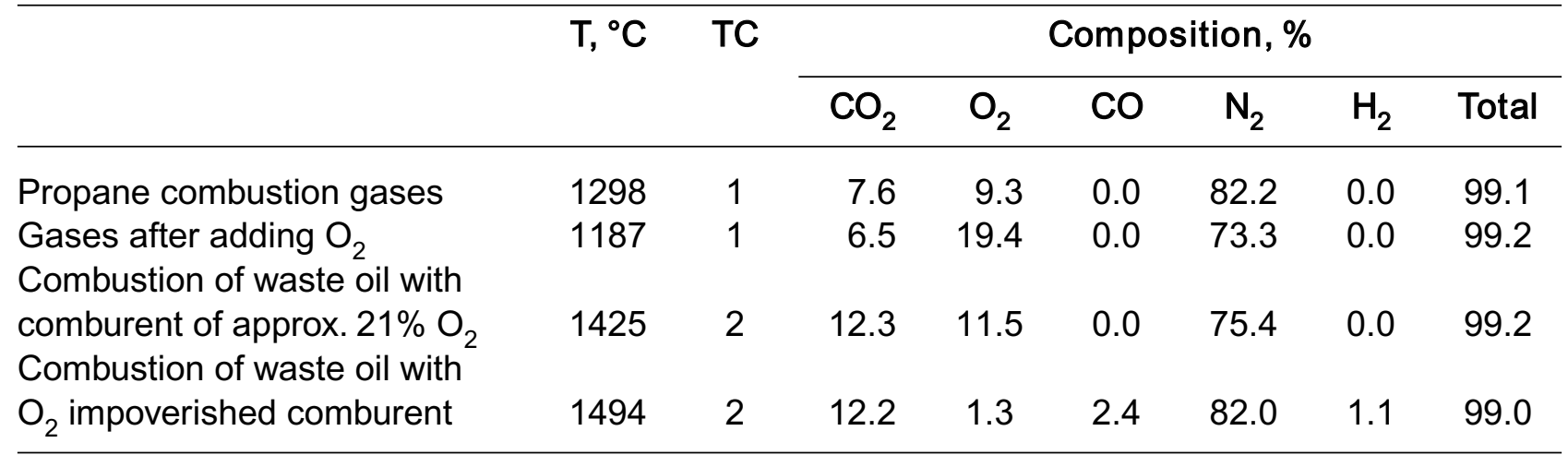

Table X. Combustion of mix of $25 \%$ depurated tinnol and $75 \%$ other waste oils

Preheating temperature: $65^{\circ} \mathrm{C}$

Flow: $10 \mathrm{~kg} / \mathrm{h}$

Tabla X. Combustión de una mezcla de $25 \%$ de tinol depurado y

$75 \%$ de otros aceites residuales

\begin{tabular}{|c|c|c|c|c|c|c|c|c|}
\hline & \multirow[t]{2}{*}{$\mathrm{T},{ }^{\circ} \mathrm{C}$} & \multirow[t]{2}{*}{ TC } & \multicolumn{6}{|c|}{ Composition, $\%$} \\
\hline & & & $\mathrm{CO}_{2}$ & $\mathrm{O}_{2}$ & $\mathrm{CO}$ & $\mathrm{N}_{2}$ & $\mathrm{H}_{2}$ & Total \\
\hline Propane combustion gases & 1225 & 1 & 5.8 & 12.1 & 0.0 & 80.9 & 0.0 & 98.8 \\
\hline $\begin{array}{l}\text { Gases after adding } \mathrm{O}_{2} \\
\text { Combustion of waste oil with }\end{array}$ & 1113 & 1 & 4.5 & 21.0 & 0.0 & 75.0 & 0.0 & 100.5 \\
\hline $\begin{array}{l}\text { comburent of approx. } 21 \% \mathrm{O}_{2} \\
\text { Combustion of waste oil with }\end{array}$ & 1197 & 2 & 6.3 & 17.7 & 0.0 & 75.0 & 0.0 & 99.0 \\
\hline $\mathrm{O}_{2}$ impoverished comburent & 1337 & 2 & 8.7 & 8.3 & 0.0 & 81.8 & 0.0 & 98.8 \\
\hline
\end{tabular}

Table XI. Combustion of depurated tinnol. Preheating temperature: $90{ }^{\circ} \mathrm{C}$ Flow: $11.1 \mathrm{~kg} / \mathrm{h}$

Tabla XI. Combustión de tinol depurado

\begin{tabular}{|c|c|c|c|c|c|c|c|c|}
\hline & \multirow[t]{2}{*}{$\mathrm{T},{ }^{\circ} \mathrm{C}$} & \multirow[t]{2}{*}{ TC } & \multicolumn{6}{|c|}{ Composition, \% } \\
\hline & & & $\mathrm{CO}_{2}$ & $\mathrm{O}_{2}$ & $\mathrm{CO}$ & $\mathrm{N}_{2}$ & $\mathrm{H}_{2}$ & Total \\
\hline Propane combustion gases & 1145 & 1 & 6.5 & 11.1 & 0.0 & 81.7 & 0.0 & 99.2 \\
\hline $\begin{array}{l}\text { Gases after adding } \mathrm{O}_{2} \\
\text { Combustion of waste oil with }\end{array}$ & 1065 & 1 & 5.8 & 21.4 & 0.0 & 74.3 & 0.0 & 100.5 \\
\hline $\begin{array}{l}\text { comburent of approx. } 21 \% \mathrm{O}_{2} \\
\text { Combustion of waste oil with }\end{array}$ & 1206 & 2 & 8.9 & 14.8 & 0.0 & 75.4 & 0.0 & 99.1 \\
\hline $\mathrm{O}_{2}$ impoverished comburent & 1296 & 2 & 10.0 & 6.5 & 0.0 & 82.5 & 0.0 & 99.0 \\
\hline
\end{tabular}


of the waste oil commences in the conditions indicated in the tables. As a result of the combustion of the waste oil, the temperature rises in a continuous way and the oxygen content falls to $11.7-17.7 \%$, depending on the conditions. In this and the following stages, the temperature of the combustion gases is recorded by thermocouple TC-2. The combustion of the waste oil may be considered complete in all the tests $(0 \%$ $\mathrm{CO})$. This stage lasts for $15 \mathrm{~min}$.

\subsubsection{Combustion of waste oil with $\mathrm{O}_{2}$ impoverished comburent}

In this final stage the oxygen supply to the combustion chamber is cut off. The waste oil continues to be injected for $15 \mathrm{~min}$ more and the test is considered to be concluded. As a result of the non-injection of oxygen, the $\mathrm{O}_{2}$ percentage falls to very low levels (1.2-8.3\%, depending on the test) and due to the scarcity of oxygen, incomplete combustion is seen in some cases, as demonstrated by the presence of $\mathrm{CO}$ (up to $2.4 \%$ ) in the analysed combustion gases.

\subsection{Combustion of new tinnol}

Tables V and VI offer the results of the combustion of this waste oil. The sum of the components of the combustion gases $\left(\mathrm{CO}_{2}, \mathrm{O}_{2}, \mathrm{CO}, \mathrm{N}_{2}, \mathrm{H}_{2}\right)$ approaches $99 \%$. For the test performed with the greatest oil flow $(20 \mathrm{~kg} / \mathrm{h})$, a slight CO content, $0.1 \%$, is seen in the final stage of the test (with scarcity of oxygen).

The temperature of the combustion gases, measured by thermocouple TC-2, increases throughout the experiment. By way of reference, the tables give the temperature recorded $10 \mathrm{~min}$ after the injection of the oil $\left(1306^{\circ} \mathrm{C}\right.$ in Table V) and 10 min after cutting off the oxygen supply to the combustion chamber $\left(1404^{\circ} \mathrm{C}\right.$ in Table V). These temperatures have a tendency to increase and are greater than those recorded in the combustion chamber before the injection of the oil, as was to be expected.

\subsection{Combustion of the $50 \%$ tinnol and $50 \%$ waste oil mix}

The results are shown in tables VII and VIII. For the greatest flow $(20 \mathrm{~kg} / \mathrm{h})$, incomplete combustion is seen $\left(2.2 \% \mathrm{CO} ; 1.1 \% \mathrm{H}_{2}\right)$ during the stage corresponding to combustion of the mix with a scarcity of oxygen.

\subsection{Combustion of the $25 \%$ tinnol and $75 \%$ waste oil mix}

The results are shown in tables IX and X. The behaviour is similar to that of the previous waste oils. At greater flows $(17.5 \mathrm{~kg} / \mathrm{h})$, and with a scarcity of oxygen, combustion is incomplete $\left(2.4 \% \mathrm{CO}, 1.1 \% \mathrm{H}_{2}\right)$.

\subsection{Combustion of depurated tinnol}

The results are shown in table XI. The test was performed with a low flow of waste oil and, in a similar way to the other waste oils, at the lowest flow the combustion may be considered complete.

\section{DISCUSSION}

A large proportion of the wastes produced in the different stages of the iron and steelmaking industry are recycled in sintering plants, forming part of the mineral mix to be sintered, with certain limitations regarding the $\mathrm{Zn}$ or alkali content of the wastes and the oil content of the mill scales ${ }^{[14]}$. It is proposed to use the waste oil as a fuel, in addition to propane, for the sintering machine ignition furnace ${ }^{[11]}$.

The injection of oil and other fuels in BF tuyeres is a widespread practice which has the objective of achieving savings in the consumption of coke per tonne of hot metal produced. In some furnaces, oil injection rates of more than $140 \mathrm{~kg} / \mathrm{tHM}$ have been achieved with coke consumptions of less than $300 \mathrm{~kg} / \mathrm{tHM}$. Operating results indicate that for oil injection rates of between 0 and $156 \mathrm{~kg} / \mathrm{tHM}$ a replacement rate of $1.18 \mathrm{~kg}$ coke $/ \mathrm{kg}$ oil can be achieved $^{[15]}$. At blast furnaces No. 1 and No. 2 of Rautaruukki Raahe Steel Works, oil injection rates of up to $110 \mathrm{~kg} / \mathrm{tHM}$ have been achieved ${ }^{[16]}$.

The blast furnace is also considered for the disposal of wastes with certain limitations in terms of their impurity contents. The use of waste oils has the disadvantage of increasing the entry of sulphur into the furnace.

The injection rate of polyvinyl chloride plastics is limited by the chlorine concentration, in order to avoid corrosion problems in the throat gas pipes due to the fact that chlorine forms $\mathrm{HCl}$. Dioxin concentrations do not exceed the maximum allowable concentrations in the top gas ${ }^{[10}$ and 17$]$.

When shredder light fraction is injected, the main problem is caused by the increase in $\mathrm{Cu}, \mathrm{Cr}$ and $\mathrm{Ni}$ contents in the hot metal. No increase in dioxin concentrations in the raw gas, cleaned gas, 
dust, Cowper gas or waste water was observed during the injection process ${ }^{[9}$ and 10$]$.

When waste oil is injected in BF tuyeres, the following occurs: a) a drop in the blast temperature; b) an increase in the specific consumption of the blast, and c) an impact on the specific coke consumption. These changes depend on the waste oil injection flow and composition ${ }^{[2]}$.

With regard to coke consumption, the $\mathrm{kg}$ coke $/ \mathrm{kg}$ waste oil replacement rate is ${ }^{[2]}$ :

- waste oil with $2 \%$ humidity: coke savings of $(0.9-1) \mathrm{kg} / \mathrm{kg}$

- waste oil-water mix with 25\% humidity: coke savings of $0.5 \mathrm{~kg} / \mathrm{kg}$

- waste oil-water mix with $60 \%$ humidity: slight savings in coke consumption.

It is recommended not to inject waste oil with a humidity content of more than $20 \%$ into the furnace, and that the solid substances mixed with the waste oil should be less than $2 \mathrm{~mm}$ in size ${ }^{[2]}$.

The waste oils studied in the present work have low humidity contents, less than $8.5 \%$ (Table I). The rate of savings in coke consumption in the blast furnace, through the injection of waste oils in the tuyeres, can be estimated at (0.7-1) $\mathrm{kg}$ coke/ $\mathrm{kg}$ waste oil, taking into account this work's results and data from recent research about the calculation of coke replacement ratio by injection of several fuels by tuyeres into a blast furnace ${ }^{[18]}$.

The combustion of each waste oil with $\mathrm{O}_{2}$ impoverished comburent, when the injection rate is lower, is more complete ( $0.0 \% \mathrm{CO}$ content) than when the injection rate is higher $(0.1-2.2 \% \mathrm{CO})$ (Tables V-XI). The waste oil combustion efficiency, calculated as indicated in Appendix 2, is greater than $95 \%$ for all the waste oils in the tested conditions.

\section{CONCLUSIONS}

A study is made, in a combustion chamber installed at CENIM, of the combustion behaviour of waste oils produced in ACERALIA works. The experimental equipment simulates the conditions of the blast furnace in the tuyere zone in order to check the efficiency of the combustion of waste oils. The results obtained allow the following conclusions to be drawn:

- The fluidity conditions of the waste oils are good in the oil preheating and injection installations, prior to the combustion chamber, designed for this work. The waste oils spray well in the nozzles used.

- The waste oils undergo complete combustion when they are injected at lower flows into the combustion chamber. At greater flows, and with a scarcity of oxygen, combustion is not complete with some waste oils, as is shown by the presence of $\mathrm{CO}$ in the combustion gases.

- Taking into account the humidity content and the calorific value of the waste oils, the rate of savings in coke consumption in the blast furnace may be estimated to be (0.7-1) $\mathrm{kg}$ coke/ $\mathrm{kg}$ waste oil.

\section{REFERENCES}

[1] T.R. Meadowcroft, Iron Steelmaker 20 (1993) 33-37.

[2] Cockerill Sambre, Recycling of oily waste at Cockerill Sambre. Private communication, (1993).

[3] K.-H. Großpietsch, Usage of Recycling Material in European Blast Furnace Works, European Blast Furnace Committee, Ed. VDEh, Düsseldorf (Germany), 2003, Annex 14.

[4] M. Deguchi, S. Sasahara, T. Kasai, K. Tanaka and S. Tamura, Trans. Iron Steel Inst. Jpn. 28 (1988) 628-636.

[5] C. Feilmayr, T. Buergler, G. Brunnbauer, G. Pillmair, H. Nogratnig and G. Unterweger, Proc. $3^{\text {rd }}$ Int. Steel Conf. on New Developments in Metallurgical Process Tech., VDEh, Düsseldorf (Germany), (2007) 1052-1056.

[6] P.G. Pope and D.J. Shaw, Steel Times 224 (1996) 264-269.

[7] J. Buchwalder, J. Hunger, W. Kalinowski, W. Krüger and D. Letzel, Seminar on the Steel Industry and Recycling, Düsseldorf, Germany, April 1995.

[8] J. Hunger, W. Kalinowski, W. Krüger, D. Letzel, A. Osing and F. Schaberg, Seminar on Metallurgy and Ecology, Nancy, France, May 1993.

[9] J. Hunger, D. Letzel, W. Krüger, W. Kalinowski, J. Buchwalder, M. Schwager and D. Janke, Stahl Eisen 118 (1998) 79-86.

[10] D. Korobov, Y.S. Yusfin and D. Janke, Steel Res. 74 (2003) 403-412.

[11] A. Cores, A. Formoso, M. Sirgado, J.L. Verduras and L. Calleja, Ironmaking Steelmaking 23 (1996) 486-492.

[12] A. Babich, S. Yaroshevskii, L. Garcia, A. Cores, A. Isidro and S. Ferreira, Rev. Metal. Madrid, 32 (1996) 103-116.

[13] A. Babich, S. Yaroshevskii, A. Formoso, A. Isidro, S. Ferreira, A. Cores and L. Garcia: ISIJ Int. 36 (1996) 1.250-1.258.

[14] H.B. Lüngen, J. Aumonier, G. Berglund, M. Calcagni, P. Depaye, C. Huguet, G. Kolb, J. Putro and J. Rengersen, Proc. 3rd European 
Ironmaking Cong., Gent, Belgium, (1996), 151 158 (Joint EBFC Paper).

[15] R. Altland, M. Beseoglu, W. Lanzer and K.P. Stricker, Proc. 3rd European Ironmaking Cong., Gent (Belgium), (1996), 93-98.

[16] P. Mannila, D. Liao, J. Härkki and P. Pisilä, Proc. 2nd Int. Cong. on Sci. and Tech. of Ironmaking and 57th Ironmaking Conf., ISS, Warrendale, USA, 1998 417-424.

[17] M. Asanuma, T. Ariyama, M. Sato, R. Murai, T. Nonaka, I. Ocochi, H. Tsukiji and K. Nemoto, ISIJ Int. 40 (2000) 244-251.

[18] D. Frank Huang and R.J. Janson, Iron and Steel Tech. Conf. Proc. Vol. I Indianapolis, Indiana, USA. Association for Iron and Steel Technology (2007), 597-607.

\section{APPENDIX 1}

\section{EUROPEAN COMMUNITY ENVIRON- MENTAL PROGRAMMES}

1st EC Programme (1973) - sets out the aims and principles of environmental policy and includes basic corrective measures.

$2^{\text {nd }}$ EC Programme (1977) - an updating and extension of the first programme.

3rd EC Programme (1983) - its aim is to give a preventive approach to environmental matters. $4^{\text {th }}$ EC Programme (1987-92) - deals with prevention and control of pollution, the definition of environmental resource management and the development of research projects; the programme establishes as a priority aim a high level of environmental protection, converting this into an imperative need with an economic character.

$5^{\text {th }}$ EC Programme (1993-2000) - the posing of thei programme report that the environmental situation is serious in Europe, and their objectives are concerned with the following:

- Agents and activities that deplete the natural resources.

- To attempt to change the present harmful trends to the environment, to guarantee socioeconomic growth for the present and future generations.

- To attempt to modify the social rules of behaviour through participation by all the public sectors with the aim of sharing the responsibility, including the public administrations, public and private enterprises and the population in general as citizens and consumers.

- The responsibilty to be shared by means of a wider range of instruments. $6^{\text {th }}$ EC Programme (2002-2012) - the Parliamentary hearings of the Prodi Commissions Members in September 1999 was in favour of a $6^{\text {th }}$ Environment Action Programme. The Commission proposal to the European Parliament and Council was presented in January 2001 (full text).

The preparatory work was based in part on:

- The Global Assessment of the $5^{\text {th }}$ Environmental Action Programme.

- Consultions with and comments from Member States, Candidate Countries and staketholders during 2000:

- Member States' seminars

- Industry/enterprise staketholders seminars

- Comments from environmental organisations

- Comments from industry and business organisations

- Comments from regional administrations and organisations

- Candidate Countries' input and their viewpoint of environmental NGOs in the Candidate Countries

- The position of the European Institutions:

- The European Council

- The Economic and Social Committee

- The Committee of Regions

- Comment received throught a mail box open on this web site from November 1999 to July 2000

- The 1999 State of Environment Report present by the European Environment Agency in June 1999 and the results of the 1999 Eurobarometer. The basic objectives of these programmes can be defined as follows:

(i) The application of the principle "the polluter pays"

(ii) The need to reduce pollution at its source

(iii) The need to reduce or eliminate crossborder pollution

(iv) The development of clean technologies

(v) The improvement of all types of waste management, including the reduction of volumes of waste through treatment, reuse, and most importantly, recycling.

\section{APPENDIX 2}

\section{EFFICIENCY OF COMBUSTION}

The efficiency of the combustion of the waste oil is calculated by applying equation (7), which is obtained in the following way:

a) Waste oil flow, in $\mathrm{kg} / \mathrm{h}\left(\mathrm{C}_{1}\right)$ 
COMBUSTION OF WASTE OILS SIMULATING THEIR INJECTION IN BLAST FURNACE TUYERES COMBUSTIÓN DE ACEITES RESIDUALES SIMULANDO SU INYECCION EN LAS TOBERAS DEL HORNO ALTO

$$
\mathrm{C} 1=\mathrm{kg} \text { spent } \times 60 / \text { Test duration, } \min
$$

b) Carbon flow, in $\mathrm{kg} / \mathrm{h}\left(\mathrm{C}_{2}\right)$

$$
\mathrm{C}_{2}=\mathrm{C}_{1} \times \mathrm{C} \text { dry sample / (100 + humidity) (3) }
$$

c) Oxygen flow, $\mathrm{m}^{3} / \mathrm{h}\left(\mathrm{C}_{0}\right)$

$$
\mathrm{C}_{0}=\mathrm{O}_{2} \text { spent } \times 60 / \text { Test duration, min }
$$

d) Air flow dry comburent, $\mathrm{m}^{3} / \mathrm{h}\left(\mathrm{Q}_{1}\right)$

$$
\mathrm{Q} 1=\frac{\mathrm{C}_{0}\left(100-\% \mathrm{O}_{2} \text { before the injection of } \mathrm{O}_{2}\right)}{\% \mathrm{O}_{2} \text { after injection }-\% \mathrm{O}_{2} \text { before injection }}
$$

e) Flow of dry combustion gases, $\mathrm{m}^{3} / \mathrm{h}\left(\mathrm{Q}_{2}\right)$

$$
\mathrm{Q}_{2}=\frac{\mathrm{Q}_{1}\left(\% \mathrm{~N}_{2} \text { in the comburent }\right)}{\% \mathrm{~N} 2 \text { in the combustion gases }}
$$

f) Efficiency of the combustion of the waste oil, \% (E)

$$
E=\frac{12[\% \mathrm{CO}+\% \mathrm{CO} 2) \times Q 2-01(\% \mathrm{CO} 2 \text { in thy e comburent }]}{22.4 \times \mathrm{C2}} \times 100(7)
$$

The application of this equation to the results presented in tables V-XI makes it possible to calculate the combustion efficiency of each waste oil for each experimental condition. In all cases the efficiency is greater than $95 \%$. 